\title{
Waria Dan Upayanya dalam Meraih Kapital Simbolik: Studi Kasus Pengajian Al-Ihklas dan Persekutuan Doa Hati Damai dan Kudus
}

\author{
Lastiko Endi Rahmantyo \\ Departemen Sastra Inggris, Fakultas Ilmu Budaya, Universitas Airlangga, \\ Jl. Dharmawangsa Dalam Selatan, Surabaya, Indonesia. \\ E-mail:lastikoendi@gmail.com
}

\begin{abstract}
Transgender and religion have always been two contradictory things called as oxymoron. All religions do not admit the discourse of transgender and it does happen in Surabaya. The discrimination and stigma attached to them have made them avoid the religious places. It is the notion happening in most of transgender because they are shy and felt that they did not belong to it. Interestingly, there were two religious affiliations created and addressed for transgender in Surabaya: Pengajian Al-Ikhlas (for Moslems) and Persekutuan Doa Hidup Damai dan Kudus (for Christians). By the time this thesis was finished, the two religious organizations have already grown up for more than ten years and still exist and keep developing. The theory used in this thesis was Pierre Bourdieu's Habitus, Field, and Capital. It was used to analyse how those two affiliations were built and developed. The method used was qualitative method by using ethnographic research. The primary data used were the data from the interviews and participatory observation; while the secondary data were from documents such as newspapers and magazines. The results of this thesis indicated that the Habitus owned and internalized by the owner of these affiliations were the major reason on why these affiliations were grown and developed. It was also facilitated by the field in Surabaya that made them comfortable. Furthermore, capital was also noted to be the one that keeps the affiliations running. The attendants were having extra care within their death, extra cash, socialization, and also the most important was being recognized as citizens.
\end{abstract}

Keywords: oxymoron, Pengajian Al-Ikhlas and Persekutuan Doa Hidup Damai dan Kudus, habitus, field, capital

\section{Pendahuluan}

Waria merupakan salah satu fenomena gender dan seksualitas yang ada di pelbagai sudut dunia, tak terkecuali di Indonesia. Dengan menyandang sebagai salah satu negara dengan penduduk terbanyak di dunia, Indonesia, khususnya Surabaya juga merupakan kota dengan jumlah waria terbanyak (Departemen Kesehatan, 2009:32). Banyaknya jumlah waria di Surabaya merupakan cerminan umum dari kota metropolitan dimana banyak orang yang datang untuk mencari pekerjaan di kota, termasuk waria. Selain itu, pola migrasi para waria di kota dikarenakan peluang untuk mendapatkan pekerjaan di kota lebih besar mengingat mayoritas waria yang bekerja di kota 
merupakan waria yang tidak diterima di keluarganya dan memilih untuk mencari nafkah di kota (wawancara dengan responden A, 17 April 2011).

Banyaknya jumlah waria di Surabaya juga diikuti dengan tumbuhnya organisasi yang menaungi mereka. PERWAKOS (Persatuan Waria Kota Surabaya) yang juga merupakan organisasi waria terbesar dan tertua di Indonesia telah banyak memberikan bantuan dalam bentuk materi maupun dukungan terhadap kaum transgender yang ada di Surabaya. Oleh karena itulah, organisasi ini berkembang seiring dengan tumbuhnya populasi waria di Surabaya. Dalam kesehariannya, waria sering mengalami diskriminasi dan stigma negatif oleh kaum heteroseksual. Banyak dari mereka yang dilecehkan baik secara verbal maupun secara fisik, bahkan ada juga yang sampai mengalami cedera serius (Ariyanto dan Triawan, 2008). Diskriminasi dan stigma negatif yang dialamatkan pada waria bahkan sampai ke kebebasan menjalankan ibadah keagamaan. Artinya bahwa untuk waria, beribadah pun sulit untuk dilakukan. Hal ini seolah-olah menjadi sebuah tamparan keras bahwa kebebasan beragama dan beribadat seperti yang diamanatkan oleh Undang Undang Dasar Republik Indonesia tahun 1945 pada pasal 29 ayat 2 hanya berlaku untuk kaum-kaum tertentu.

Dengan diskrimasi yang muncul dalam berbagai bentuk tersebut, waria seolah-olah berada di dalam penjara. Bahkan mungkin lebih buruk dari penjara karena untuk melakukan kebaikan pun mereka juga tidak bisa. Atas dasar inilah, di Surabaya terdapat dua organisasi keagamaan yang didirikan oleh waria untuk waria. Kedua organisasi tersebut bernama Pengajian Al-Ikhlas untuk yang beragama Islam dan Persekutuan Doa Hati Damai dan Kudus (PHDK) untuk yang beragama Kristen Protestan. Organisasi tersebut merupakan cikal bakal organisasi keagamaan waria lain yang muncul di berbagai daerah di luar Surabaya, seperti Pengajian Senin Kamis di Yogyakarta, Persekutuan Doa Hidup Baru dan Kudus di Solo, Malang, dan Semarang.

Terbentuknya organisasi keagamaan oleh waria merupakan hal yang menarik, karena sejatinya antara agama dan waria merupakan hal yang oksimoron. Sifat agama dan waria seperti sifat minyak dan air yang tidak bisa menyatu, tetapi mengapa organisasi keagamaan waria bisa terbentuk. Untuk menyatukan minyak dan air butuh sabun, hal yang sama juga terjadi pada organisasi keagamaan waria. Proses negosiasi yang berjalan antara waria dan agama inilah yang menjadi fokus utama peneliti pada karya ini. Lebih lanjut peneliti akan melihat faktor-faktor apakah yang berperan di dalam pembentukan organisasi keagamaan waria tersebut.

Pertanyaannya adalah bagaimana organisasi keagamaan waria bisa terbentuk? Apakah ada proses negosiasi yang berlangung di dalamnya? 


\section{Teori dan Metode}

Penelitian ini menggunakan trio teori yang dikemukakan oleh Pierre Bourdieau yaitu habitus, arena, dan kapital. Bourdieau mengemukakan bahwa ketiga unsur teori tersebut tidak bisa dipisahkan, artinya bahwa antar ketiganya saling berhubungan. Secara gamblang Bourdieau menyatakan bahwa: [(habitus) $($ kapital $)]+$ arena $=$ practice $($ Maton, 2008: 51). Sederhananya, habitus berfokus pada cara kita bertindak, berpikir, merasakan, dan "menjadi seseorang” (Maton, 2008:52). Termasuk bagaimana kita membawa sejarah yang pernah kita alami ke dunia yang sedang dijalani sekarang, serta bagaimana kita bertindak dengan cara tertentu tidak dengan cara yang lain. Proses ini berlangsung terus menerus, sampai bahkan mungkin menciptakan sejarah sendiri bagi kita, tetapi tidak dengan keputusan-keputusan yang kita buat secara independen, masih ada pengaruh dari masa lalu yang pernah kita tempuh (ibid).

Di sisi lain, untuk memahami interaksi antar manusia atau menjelaskan tentang fenomena sosial tidaklah cukup hanya dengan melihat apa yang dikatakan, atau apa yang terjadi (dalam hal ini sejarah). Sangatlah penting untuk melihat ranah sosial dimana terjadi interaksi, transaksi, dan kejadian. Ranah sosialinilah yang disebut oleh Bourdieu sebagai field/arena (Thomson, 2008:67). Bourdieu menganalogikan arena ini dalam tiga ranah: pada ranah sepakbola, fiksi ilmiah, dan fisika (2008:68). Ia juga menekankan bahwa tidak ada definisi mutlak tentang arena, oleh karena itu peneliti seharusnya melihat pengandaian filsafat pada ketiga ranah tersebut. Pada ranah sepak bola, arena dianalogikan seperti sebuah tempat dimana individu-individu di dalamnya mentaati peraturan yang disepakati dan berinteraksi sesuai dengan peran yang diemban masing-masing individu. Sementara pada ranah fiksi ilmiah, arena dianalogikan seperti sebuah pesawat yang mempunyai tembok penghalang untuk menghalangi partikel yang ingin menghantam pesawat ataupun menghidari partikel dari dalam pesawat yang ingin keluar. Pada wanah ini, arena membawa pengaruh bagi individu yang berada di dalamnya. Terakhir adalah pada ranah fisika, dimana Bourdieau menganalogikan arena sama dengan konsep force field, dimana meskipun terdiri atas berbagai kutub masih tetap tarik menarik (ibid). Kutub yang bermain pada ranah ini adalah kapital ekonomi dan kapital budaya seperti yang akan dijelaskan pada paragraf di bawah ini.

Di dalam dunia sosial, pelaku atau kelompok pelaku dibedakan berdasarkan dua hal: (1) besarnya kapital yang mereka miliki, dan (2) sesuai dengan bobot komposisi keseluruhan kapital mereka (Haryatmoko, 2003:12). Kapital ini sengaja diburu atau dicari oleh pelaku atau kelompok pelaku di 
dalam dunia sosial, karena memiliki kapital berarti memiliki kuasa tertentu. Bourdieu membagi kapital menjadi empat macam: (1) kapital ekonomi (uang dan aset); (2) kapital budaya (tingkat pendidikan, estetika, preferensi budaya, bahasa); (3) kapital sosial (afiliasi dan jaringan, keluarga, relijiusitas, warisan budaya); (4) kapital simbolik (sesuatu yang dapat ditukar dengan semua kapital yang ada, contohnya adalah pengakuan/rekognisi) (Thomson, 2008:69). Dari kesemua kapital yang ada, kapital ekonomi lah yang dapat dikonversi menjadi kapital-kapital yang lain, serta kapital simbolik lah yang dikejar oleh pelaku sosial sebagai puncak dari semua kapital (Haryatmoko, 2003: 12).

Metode kualitatif dipilih untuk menganalisa fenomena yang terdapat pada kedua organisasi keagamaan waria ini. Pengumpulan data didasarkan pada analisis dokumen, pengamatan terlibat (participatory observation), wawancara mendalam dengan pedomanterhadapketua, anggota, dan pemuka agama di organisasi tersebut. Terdapat dua sumber data primer dan satu sumber data sekunder yang digunakan sebagai data di dalam penelitian ini. Sumber data primer terdiri dari data observasi/pengamatan terlibat dan wawancara mendalam, sementara data sekunder diambil dari dokumen-dokumen yang terkait dengan Al-Ikhlas dan PHDK.

Pengamatan yang dilakukan adalah berpartisipasi pada kegiatan di PHDK dan Al-Ikhlas. Di PHDK, peneliti datang sebanyak tiga pertemuan, pada tanggal 14 Maret 2012, 28 Maret 2012, dan 18 Juni 2012. Sementara untuk pengajian Al-Ikhlas, pengamatan terlibat dilakukan pada tanggal 27 April 2012. Pengamatan pada pengajian hanya dilakukan satu kali karena memang pengajiannya dilakukan sebanyak sebulan sekali.

Wawancara dilakukan dengan mengambil topik pada motivasi, manfaat, dan dampak terbentuknya organisasi keagamaan ini. Tiga komponen utama yang dipilih sebagai informan adalah ketua, anggota aktif, dan pemuka agama yang rutin memberikan ceramah pada organisasi tersebut. Yang dimaksud dengan rutin adalah tiap kali diadakan persekutuan doa ataupun pengajian, maka mereka lah yang menjadi pembicara utama.

Wawancara mendalam dilakukan selama tahun 2012, tetapi ada satu responden yang diwawancarai pada tahun 2011. Adapun bulan pengambilan data wawancara adalah pada bulan Maret sampai dengan Juni 2012. Dari hasil wawancara tersebut, terdapat lima informan kunci dan delapan responden yang telah dikodekan dengan acak. Pada pelaksanaan wawancara, rata-rata lama wawancara adalah sepanjang 60 - 120 menit. Metode wawancara semi-structured dengan pertanyaan open questions. Identitas ke tiga belas responden dirahasiakan, hanya Handayani yang sudah menyatakan kesediaannya untuk dicantumkan namanya. 
Hasil wawancara akan didokumentasikan dalam bentuk transkrip wawancara. Data tersebut beserta data berita koran diklasifikasikan berdasarkan habitus, arena, dan kapital. Selain itu data juga dipakai di dalam penulisan tentang sejarah singkat organisasi keagamaan ataupun pendiri organisasi.Setelah data diklasifikasi berdasarkan ketiga kelompok tersebut, peneliti akan melakukan interpretasi dengan menggunakan teori Bourdieu tentang habitus, arena, dan kapital. Selain itu, peneliti juga akan menulis tentang bagaimana negoisasi yang terjadi antara dua elemen, waria dan agama, sehingga organisasi keagamaan ini bisa terbentuk dan berkembang.

\section{Hasil dan Pembahasan}

\section{Sejarah Singkat PHDK dan Pengajian Al-Ikhlas.}

PHDK merupakan organisasi keagamaan waria untuk pemeluk agama Kristen Protestan yang pertama kali ada di Indonesia (wawancara dengan Handayani, 27 April 2012). Proses berdirinya PHDK tidak melalui jalan yang mulus, tetapi melalui jalan yang terjal, dengan berbagai rintangan yang menghalangi sampai organisasi ini terbentuk pada tahun 1993 (ibid).

Sebagai ketua sekaligus pendiri dari PHDK, Handayani, mengungkapkan bahwa latar belakangnya mendirikan PHDK adalah karena ia telah tobat menjalani kehidupan sebagai waria yang tidak dekat dengan Tuhan (Anggraeni, 2003). Pada mulanya, Handayani membentuk organisasi ini dengan tujuh orang teman waria yang seiman. Alasan mereka mendirikan PHDK adalah untuk menampung waria yang malu untuk datang beribadah ke gereja.

Dukungan dana dan bantuan dalam bentuk materi pada mulanya bersifat independen, artinya PHDK maju hanya dengan menggunakan dana iuran oleh para anggotanya. Seiring dengan berjalannya waktu, PHDK mendapat bantuan dari Yayasan Pondok Kasih dan Gereja Bukit Zion. Bantuan yang diberikan oleh kedua organisasi tersebut berwujud tidak hanya dalam bentuk materi, tetapi juga pelayanan kesehatan, dan juga dalam bentuk penceramah yang datang pada saat persekutuan doa (wawancara dengan Handayani, 27 April 2012).

PHDK yang dahulu bernama PD WGL (Persekutuan Doa Waria Gay Lesbi) melaksanakan kegiatan rutinnya setiap hari Selasa (minggu kedua) dan Jumat (minggu keempat) pada pukul 18.00 WIB. Pada persekutuan doa tersebut, jemaat yang datang beragam, mulai dari waria yang tingkat ekonominya rendah (ditandai dengan jenis pekerjaan) sampai dengan waria yang tingkat ekonominya menengah keatas (ditandai dengan kepemilikan salon). Kegiatan persekutuan doa dilaksanakan di Salon Handayani yang berada di daerah Bratang, dan pada tiap kegiatannya jumlah jemaat yang 
datang tidak sampai maksimal sesuai dengan jumlah anggotanya yang mencapai 80 orang. Hal tersebut mungkin terjadi karena waria mempunyai kesibukannya sendiri-sendiri.

Selain kegiatan yang dilaksanakan di salon Handayani, persekutuan doa juga dilaksanakan di Bukit Zion. Persekutuan waria yang dilakukan di Bukit Zion disebut dengan Adulam. Adulam merupakan nama sebuah gua yang isinya masyarakat yang terpinggirkan di masyarakat, mulai dari orang yang tidak pernah membayar hutang, penjahat, dan lain-lain dibawah pimpinan Raja Daud. Kemudian, setelah bertemu dengan Raja Daud mereka bisa dibina, dan ketika keluar dari gua tersebut, mereka menjadi anak buah Raja Daud (wawancara dengan responden B, 21 Juni 2012). Dari nama tersebut, tersirat pemahaman bahwa persekutuan doa Bukit Zion memang bertujuan untuk "membina" waria untuk kembali menjadi keadaan biologisnya.

Usia peserta PHDK juga beragam,ada yang berusia muda (kisaran 20 tahunan), dan ada pula yang berusia lanjut (kisaran 60 tahunan). Mereka duduk bersama dalam satu ruangan untuk berdoa bersama dan memanjatkan pujian untuk Tuhan. Mayoritas peserta PHDK (sekitar 90\%) adalah waria. Untuk mencari anggota, Handayani bersikap proaktif. Kala ia mendengar ada waria yang sedang sakit, tidak hanya Kristen tetapi juga agama lain, Handayani biasanya mendatanginya dan menawarkan doa kesembuhan. Setelah sembuh, biasanya waria tersebut datang ke PD dan kemudian mengikuti acara PD. Bahkan ada beberapa waria yang kemudian beralih kepercayaan (convert).

Hambatan yang datang dalam pendirian PD tidak datang dari masyarakat sekitar, tetapi malah datang dari pendeta yang sinis dengan keberadaan waria.

"Penduduk sekitar ga masalah, mendukung, justru pro kontranya adalah pendeta-pendeta itu ada yang menentang (bukan menentang tapi meremehkan), "halah wong waria kok ngadakan persekutuan doa, paling yo guyon-guyon tok hepi-hepi tok." "Waria saja kok mengadakan persekutuan doa, paling yang ada hanya bercanda dan tidak serius.")

Oleh karena itulah, Handayani bertekad untuk menjadikan PHDK ini sebagai organisasi keagamaan yang memang bertujuan untuk beribadah bukan untuk mencari kesenangan semata.

PHDK juga tercantum pada struktur organisasi PERWAKOS yaitu pada seksi kerohanian. Jika ada waria yang beragama Kristen dianjurkan untuk mengikuti ibadat yang dilakukan oleh PHDK, sementara jika ada waria Islam maka diarahkan untuk mengikuti ibadah di pengajian Al-Ikhlas.

Pengajian Al-Ikhlas telah berdiri sejak tahun 2003 dengan anggotanya saat itu sebanyak 19 orang dan semuanya telah berusia 30 tahun keatas (wawancara dengan responden J, 11 Mei 2012). 
Latar belakang pendirian pengajian ini kurang lebih sama dengan PHDK yaitu untuk mengakomodir keinginan waria yang beragama Islam untuk melakukan ibadah.

Lain halnya dengan PHDK yang telah memiliki tempat tetap untuk melakukan peribadatan, pengajian Al-Ikhlas tidak memiliki lokasi khusus untuk beribadat. Pola pengajian yang dilaksanakan sebulan sekali ini mirip dengan pola arisan ibu-ibu yang tiap bulannya dilakukan di tempat yang berbeda. Giliran menjadi tuan rumah biasanya diundi dan dalam satu tahun tidak ada yang menjadi tuan rumah sebanyak dua kali. Hal ini dilakukan agar semua anggota mendapatkan kesempatan yang samamenjadi tuan rumah. Sampai saat ini, pengajian sudah dilakukan di berbagai kota di Jawa Timur sesuai domisili anggota pengajian tersebut. Anggota pengajian ada yang berdomisili di Gresik, Lamongan, Malang, Madura dan Surabaya (wawancara dengan informan B, 1 Mei 2012). Metode berpindah-pindah bertujuan untuk menunjukkan pada masyarakat bahwa waria tidak hanya pekerja seks atau pengamen di jalan-jalan, tetapi ada juga waria yang mengadakan pengajian (wawancara dengan informan A, 11 Mei 2012).

Sampai saat penelitian ini dilakukan, anggota yang terdaftar pada pengajian ini sejumlah 80 orang. Jumlah tersebut tidak selalu datang rutin dalam pengajian, sehingga jarang sekali pengajian dilakukan dengan jemaah sampai dengan 80 orang. Fenomena tersebut berbeda ketika pengajian untuk memperingati Idul Fitri digelar. Pada saat itu, waria yang datang pada pengajian mencapai sekitar 300 orang, karena tidak hanya waria yang beragama Islam saja yang datang melainkan semua waria biasanya datang pada acara-acara besar seperti Idul Fitri dan Natal.

Pada saat pengajian, para waria tersebut tidak berpenampilan seperti wanita, tetapi mengenakan pakaian putih-putih seperti laki-laki dan tanpa make-up. Menurut informan B, mereka pada dasarnya adalah laki-laki, maka ketika beribadah, sholat, ataupun pengajian harus berpakaian seperti layaknya laki-laki (1 Mei 2012). Meskipun berpenampilan seperti laki-laki, masih banyak modifikasi pakaian yang mereka lakukan sehingga pakaian laki-laki lebih mirip seperti perempuan. Contohnya adalah adanya beberapa waria yang masih memakai kerudung penahan rambut, serta ada juga waria yang sengaja menggerai rambutnya.

Pengajian yang dilaksanakan pada hari Jumat Legi(menurut penganggalan Jawa) dengan mengambil waktu selepas pukul 20.00 ini pernah sekali mengalami pergantian ustadz. Isi ceramah yang diberikan oleh kedua $u s t a d z$ tersebut dasarnya sama, yaitu berusaha untuk mengembalikan waria ke keadaan biologis sebagai laki-laki (wawancara dengan informan B, 1 Mei 2012).

"Nek kyai sing biyen iku ojo takon mas, nek ngomong langsung jleb-jleb." 
(“Jika kyai yang dahulu itu memang cara bicara langsung "to the point.")

Menurut informan A, cara ustadz pertama memberikan ceramahnya terlalu heteronormatif, yang seringkali memojokkan waria, sehingga banyak yang merasa tersinggung dan kemudian menggantinya dengan ustadz yang lain (wawancara dengan informan A, 11 Mei 2012). Bahkan terkadang ustadz pertama lupa bahwa anggota pengajian semuanya adalah waria, sehingga hal ini lah yang menjadi pengganjal bagi waria.

Fenomena yang terjadi pada pendirian kedua organisasi tersebut sedikit memberikan gambaran tentang negosiasi yang terjadi antara waria, agama, dan pemuka agama. Oleh karena itu pada sub bab berikut ini peneliti akan menjabarkan dengan lebih detil negosiasi yang terjadi dalam pandangan teori Bourdieu.

\section{Negosiasi yang terjadi pada PHDK dan Pengajian Al-Ikhlas.}

Seperti yang telah dijabarkan pada sub bab teori dan metodologi, dalam sebuah praktik terdapat faktor-faktor yang tidak dapat dipisahkan yaitu habitus, arena, dan kapital. Ketiga unsur tersebut terlihat dan menjadi sebuah kajian yang menarik apabila dikaitkan dengan berdiri dan langgengnya organisasi keagamaan waria di Surabaya.

\section{Habitus}

Pertama adalah penjelasan tentang habitus. Pada bab ini, peneliti akan menggambarkan tentang kehidupan masa lalu waria dapat mempengaruhi kehidupan waria sekarang, terutama yang erat hubungannya dengan organisasi keagamaan waria. Pada beberapa anggota baik pengajian ataupun perkeutuan doa waria, terdapat pola habitus yang sama, yaitu mereka berasal dari lingkungan yang agamis.

"Saya muslim dari kecil. Saya dulu sering mbantu-mbantu istrinya pak Kyai di desa, jaman dulu kalo temen saya ngaji saya dipanggil disuruh belanja kebutuhan kyai tadi" (wawancara dengan informan A, 11 Mei 2012)

"Saya itu berasal dari keluarga ningrat di daerah Jepara dan hampir seluruh keluarga saya Haji" (wawancara dengan responden I, 27 April 2012)

“Mak Anik yang berlatar belakang keluarga agamis...." (Nuraini, 2011) 
Ketiga hasil wawancara tersebut menunjukkan bahwa memang ada keterkaitan antara latar belakang kehidupan mereka dengan apa yang mereka lakukan sekarang. Pola waria, baik anggota ataupun ketua, yang berasal dari keluarga yang agamis memberikan bukti bahwa habitus berfokus pada cara kita bertindak, berpikir, merasakan dan "menjadi seseorang" (Maton, 2008:52).Selain berasal dari keluarga atau pernah bekerja di lingkungan yang agamis, ada juga yang menyatakan bahwa keterlibatannya pada organisasi keagamaan ini merupakan b2alasan dari perbuatan yang mereka lakukan di masa lalu.“'Oh ini saya dapet barokahnya pak Kyai”(wawancara dengan informan A, 11 Mei 2012).informan A yang dulunya yang bekerja di lingkungan pesantren merasa bahwa semua rejeki yang ia dapat merupakan berkah dari kyai yang pernah ia bantu dahulu.

\section{Arena}

Organisasi keagamaan waria juga dapat berdiri dikarenakan adanya arena yang mendukung mereka. Pada arena sosial, Bourdieu mengandaikannya sebagai sebuah pesawat yang mempunyai tembok penghalang sebagai filter dari dalam ke luar dan luar ke dalam.Pada pelaksanaan organisasi keagamaan, tembok penghalang itu juga nampak.Tembok tersebut adalah konsepsi masyarakat tentang waria dan agama.Tidak hanya penduduk sekitar yang terkadang "meremehkan" waria yang mengadakan organisasi keagamaan, tetapi ada juga pemuka agama yang menganggap bahwa organisasi keagamaan waria merupakan organisasi yang sifatnya tidak serius dan terkesan asalasalan.Oleh karena itu, pasti terdapat perbedaan antara bagaimana waria merepresentasikan dirinya di dalam dan di luar organisasi.Artinya bagaimana waria melaksanakan ibadahnya ketika dilakukan di lingkungan sendiri dan lingkungan umum.

Ketika ibadah dilakukan di lingkungan sendiri, seperti contohnya ibadah PHDK dilaksanakan di salon Handayani, waria lebih bisa mengkespresikan diri dan curhat sesuai dengan apa yang ada di dalam hatinya. Itu artinya mereka merasa aman dan bisa bertindak otonom. Tetapi keadaannya akan menjadi berbeda apabila waria tersebut sedang berada di gereja. Suasana guyubdan apa adanya seakan hilang apabila mereka sudah masuk ke gereja. Suasana yang muncul di gereja seakan menjadi kaku dan curhatnya tidak berkutat pada permasalahan hidup, tetapi lebih ke ungkapan rasa terima kasih kepada Tuhan yang telah memberikan rejeki dan berkah di dalam hidup.Suasana yang terlihat sangat normatif, tidak ada lagi ungkapan perasaan yang spontan keluar dari dalam hati, tetapi diproses dahulu kemudian baru diutarakan. 
Perasaan aman untuk mengutarakan perasaan ketika peribadatan dilakukan di dalam salon mengindikasikan bahwa tidak ada ancaman yang dialamatkan pada mereka.Berbeda dengan ketika mereka di gereja, yang secara konseptual harus resmi dan normatif.Hal tersebut yang membuat waria tidak bisa "melepaskan" perasaannya saat berada di dalam gereja. Konsepsi masyarakat akan waria dan agama menjadi tembok atau filter sehingga muncul pembeda antara waria di dalam dan di luar.

Tembok yang kedua adalah tembok norma keagamaan atau pandangan waria di dalam agama, dalam hal ini dalam agama Islam dan Kristen. Menurut pemuka agama yang diwawancarai, menjadi waria memang tidak diperbolehkan.Oleh karena itu, tujuan akhir pembinaan waria ini adalah supaya mereka kembali ke jenis kelaminnya.Tetapi selalu ada premis dari semua pemuka agama yang diwawancarai bahwa mengubah mereka itu sulit.Artinya selama ini masih ada ruang bagi waria di agama, dan itu diperbolehkan oleh pemuka agama. Pemuka agama tidak semata-mata menghentikan sifat waria mereka seketika tetapi ada proses yang dilakukan.

Hal tersebut mengindikasikan bahwa tembok yang dikatakan Bourdieu sebagai force field tadi tidak kokoh dan masih ada peluang untuk ditembus.Penembusan ini bisa berupa negoisasi yang dilakukan antara waria dan pemuka agama.Bentuk negoisasi tersebut bermacam-macam.Pada pengajian AlIkhlas bentuk negoisasinya adalah tidak memakain make-up dan memakai pakaian laki-laki serta fokus dari ceramah adalah pada aqidah (pada hati) bukan pada syariat(pada aturan). Pada persekutuan doa, pembacaan ayat-ayatnya tidak secara signifikan menyuruh mereka untuk kembali menjadi lakilaki, dan ketika di gereja, nama panggilan mereka bukan nama warianya, tetapi nama aslinya. Jadi ada semacam kelunakan yang diberikan oleh pemuka agama di dalam pelaksanaan organisasi ini sehingga bisa berjalan dan berkembang.

\section{Kapital}

Poin ketiga yang dibahas adalah poin tentang kapital, dimana kapital ini menjadi penyemangat bagi waria baik dalam mengikuti ataupun mendirikan organisasi keagamaan waria. Kapital selalu diburu atau dicari oleh pelaku di dalam dunia sosial, karena memiliki kapital berarti memiliki kuasa tertentu.Hal ini juga terjadi pada peserta organisasi keagamaan waria. Pada bab ini akan dijelaskan tentang manfaat yang didapat oleh peserta organisasi keagamaan di dalam pelaksanaan ibadah rutin 
organisasi. Dalam pelaksanaannya, manfaat tersebut akan dibagi menjadi empat manfaat yaitu kematian, sosialisasi, ekonomi, dan rekognisi.

\section{Waria dan Kematian}

Semua manusia pasti akan menemui ajalnya. Baik pria, wanita, waria, dan seluruh makhluk hidup lainnya pada akhirnya pasti akan mati. Bagi sebagian orang, kematian merupakan hal yang sakral dan terdapat aturan tertentu untuk menghormati orang yang meninggal. Contohnya pada saat orang Islam yang meninggal, ritual yang dijalani meliputi pemandian jenazah, sholat jenazah, dan prosesi penguburan yang penuh dengan doa-doa pengiring jenazah. Hal tersebut pasti akan mudah dilakukan, baik oleh keluarga ataupun masyarakat sekitar apabila yang meninggal adalah pria atau wanita. Sebaliknya pada waria, diskriminasi yang terjadi berlanjut sampai saat mereka meninggal.

Stigma yang melekat pada waria sebagai pekerja seks tidak bisa begitu saja hilang pada pandangan masyarakat. Stigma negatif tersebut begitu kuat, sehingga bahkan sampai meninggal pun waria masih mengalaminya. Pemuka agama terkadang ragu untuk memandikan waria karena secara tubuh, mereka tidak bisa dikategorikan sebagai pria atau wanita, sehingga tidak ada peraturan untuk mereka (wawancara dengan responden A, 17 April 2011). Anggota keluarga pun tidak tahu ketika anggota keluarga yang merupakan waria tersebut meninggal. Hal ini dikarenakan kebanyakan waria “diacuhkan” oleh keluarganya (Boellstorff, 2011:166). Mirisnya, banyak waria yang memilih untuk dimandikan di Rumah Sakit karena pihak Rumah Sakit cenderung memandikan jenazah sesuai dengan jenis kelaminnya. Mereka lebih memilih cara ini daripada dibawa pulang untuk dimandikan secara adat di daerah asalnya (ibid, 2011). Di Yogyakarta, terdapat sebuah komplek pemakaman yang ditujukan untuk orang-orang yang tidak memiliki KTP (Kartu Identitas Penduduk). Mulai dari pengamen, kaum tuna wisma, dan waria banyak yang dimakamkan di komplek ini. Seperti yang tertuang didalam kutipan ini "They die in street, in the public space. So the government takes them and buries them here" (Terje, 2011).

Kebutuhan waria akan prosesi kematian yang "layak" pun ditangkap dengan cermat oleh kedua organisasi keagamaan waria yang sedang diteliti, Al-Ikhlas dan PHDK. Pada tahun 2007, ketika ada seorang waria anggota Pengajian Al-Ikhlas yang meninggal di Tulangan, Sidoarjo yang langsung dikubur tanpa disholati merupakan salah satu alasan mengapa pengajian Al-Ikhlas dibentuk (Nuraini, 2011). Oleh karena itu, pengajian ini secara rutin mengumpulkan dana wajib yang digunakan untuk 
membantu rekan-rekan waria yang meninggal. Selain itu, ketika ada waria anggota pengajian yang meninggal, para rekan-rekan pengajian yang lain belajar untuk memandikan dan mensholati rekan mereka yang meninggal (wawancara dengan informan B, 1 Mei 2012). Sampai sekarang, apabila ada rekan waria yang meninggal, majelis pengajian Al-Ikhlas akan datang ke rumah yang bersangkutan untuk membantu memandikan dan mensholati apabila anggota keluarga yang bersangkutan tidak berkenan melakukannya.

Di sisi lain, perihal kematian ini juga merupakan alasan mengapa peserta organisasi keagamaan ratarata sudah "berumur." Rata-rata usia anggota pengajian dan persekutuan doa ini adalah sekitar 27 tahun keatas. Pada usia-usia tersebut, sudah mulai muncul kebutuhan rohani manusia akan Tuhan (Megasari, 2011). Kebutuhan mereka untuk mendekat pada Tuhan juga muncul karena ketakutan mereka akan kematian. Responden saya mengatakan "Mangkane nek wis tuek ojo aneh-aneh, wis nang omah ae, ga usah masang-masang silikon" yang dalam bahasa Indonesia artinya "Makanya, kalau sudah tua jangan aneh-aneh, di rumah saja, tidak usah memasang silikon (wawancara dengan informan A, 11 Mei 2012)." Terbersit secara implisit pada kalimat tersebut bahwa waria yang memakai silikon seakan menanggung beban saat mereka meninggal.

PHDK telah menjalin kerjasama dengan Peti Mati ARIO Surabaya yang khusus menangani kematian. Kerjasama yang dijalin adalah dengan memberikan peti mati gratis bagi waria anggota PHDK yang meninggal (wawancara dengan Handayani, 27 April 2012). Selain kerjasama dengan Peti Mati ARIO, PHDK juga menjalin kerjasama dengan Yayasan Pondok Kasih untuk mendirikan panti jompo khusus waria (ibid, 2012). Pendirian ini masih menjadi sebuah wacana yang digulirkan, dan sampai tulisan ini ditulis masih mencari donator untuk pendiriannya.

Langkah-langkah yang dilakukan oleh organisasi keagamaan dalam kaitannya dengan proses kematian waria merupakan salah satu pemancing mengapa banyak waria berminat untuk bergabung. Hal-hal tersebut tidak akan bisa terlaksana apabila tidak ada sebuah kelompok yang memperjuangkannya. Seperti kata pepatah "bersatu kita teguh, bercerai kita runtuh" mungkin merupakan ungkapan yang tepat untuk menggambarkan organisasi keagamaan waria ini. Dengan terbentuknya organisasi keagamaan ini, kapital sosial untuk menghadapi kematian dengan cara yang layak menjadi sesuatu yang telah dicapai dan diimpikan oleh waria anggota. 


\section{Waria dan Sosialisasi}

Kumpul-kumpul, bercengkrama, hangout, kongkow merupakan cara waria untuk bergaul di dalam komunitasnya. Waria yang datang di kota besar pasti akan berkumpul di dalam komunitas waria untuk mencari mentor. Mentor yang dijadikan acuan oleh para waria muda pastilah waria senior yang sudah mempunyai nama di dalam komunitasnya, dan biasanya para mentor ini menjadi cultural broker (Kortschak, 2011). Mentor ini bertugas memberikan wawasan dan wacana terhadap waria muda tentang keadaan di kota besar. Oleh karena itu, biasanya waria tua dan muda memainkan peran sebagai "ibu" dan "anak" di dalam pergaulannya dan tidak jarang seorang waria pendatang pasti ditanyai siapa “ibu” nya (wawancara dengan responden G, 27 April 2012).

Waria selalu membutuhkan wadah untuk menunjukkan eksistensinya.Menunjukkan bahwa mereka "ada" dan "diterima" oleh masyarakat.Di Surabaya sendiri, dimana jumlah waria menempati posisi tertinggi di Indonesia,terdapat perlakuan khusus bagi waria.Walikota Surabaya Poernomo Kasidi menunjuk Jalan Irian Barat sebagai tempat mereka bersosialisasi pada tahun 1980an. Pada saat itu awalnya memberikan Jalan Irian Barat sebagai tempat berkumpul kaum waria untuk bersosialisasi, tetapi seiring dengan berjalannya waktu lokasi tersebut berubah menjadi tempat 'mangkalnya' pekerja seks waria. Hingga saat ini Jalan Irian Barat terkenal sebagai tempat lokalisasi waria di mata masyarakat umum. Pemerintah seolah tidak ada masalah dengan 'lokalisasi' waria tersebut pada awalnya, tetapi akhir-akhir ini, sekitar tahun 2010 dan 2011 terdapat banyak sekali penertiban yang dilakukan di daerah Irian Barat (wawancara dengan responden A, 17 April 2011). Banyaknya pekerja seks waria yang "mangkal" di daerah tersebut membuat waria yang tidak berprofesi sebagai pekerja seks enggan untuk berkumpul di tempat itu.

Keberadaan organisasi agama menjadi salah satu tempat bersosialisasi bagi para waria yang tidak berprofesi sebagai pekerja seks.

"Sebelum ada didirikan pengajian, anak-anak berkumpulnya di jalanan, sebagai waria malam, ya dengan kegiatan yang sangat-sangat negatif. Dengan adanya pengajian, kita ingin menghilangkan kenegatifan tersebut juga stigma dan diskriminasi terhadap waria" (wawancara dengan responden $\mathrm{J}$, 11 Mei 2012)

Dari kutipan diatas, dapat diketahui bahwa waria yang tidak berprofesi sebagai pekerja seks tidak mau berkumpul di jalan, oleh karena itu tempat pengajian merupakan tempat bagi mereka untuk 
bertemu dan bersosialisasi.Selain itu, dari data yang diambil pada saat observasi, forum pengajian tersebut lebih condong untuk dijadikan ajang sosialisasi daripada pendalaman agama. Hal tersebut juga diiyakan oleh responden $\mathrm{J}$ :

"Kalo saya kok dari pengajian itu ga dapet apa-apa, ya saya suka kumpul-kumpulnya aja.Kalo ilmu saya dapetnya dari pengajian temen-temen KBIH saya" (wawancara dengan responden J, 11 Mei 2012).

Di tempat tersebut, ketika ustadz sedang berceramah, anggota pengajian yang lain tidak seberapa memperhatikannya, melainkan mereka asyik berbicang-bincang dengan anggota yang lain. Meskipun sudah ditegur oleh pemuka agama pun, mereka diam sejenak kemudian tetap berbincang-bincang dengan rekan-rekannya.

Pergantian ustadz dari yang lama yang cenderung heteronormatif dan "keras" ke kyai yang lebih "lunak" dan "sabar" memperlihatkan tujuan waria yang lebih condong ke bersosialisasi daripada ke pendalaman agama.

"Paham betul, mengikuti keinginan anak-anak. Maksudnya saya adalah waria yang sama dengan wanita (Pak informan B bisa) lebih ngemong” (wawancara dengan responden J, 11 Mei 2012).

Meskipun mempunyai prinsip yang sama di dalam ajarannya, tetapi informan B merupakan pribadi yang lunak dan lebih bisa menerima waria.

"Tambah banyak yang ayu-ayu lo, itu berarti Pak informan B ga sukses" (wawancara dengan responden J, 11 Mei 2012).

Dari segi penampilan, dengan adanya informan B ini waria lebih coming out daripada ketika masih diketuai oleh Kyai yang lama.Meskipun tidak menggunakan make-up dan memakai baju laki-laki serba putih tetapi penampilan waria lebih menunjukkan pribadi sebagai wanita daripada sebagai lakilaki.Hal ini membuktikan bahwa habitus hexis yang mereka bawa masih kental terlihat meskipun dibalut dengan pakaian laki-laki dan tanpa make-up.

\section{Waria dan Ekonomi}

Mayoritas waria yang "hijrah" ke kota besar karena memang tidak diakui oleh keluarga dan pada akhirnya "dibuang” oleh keluarga. Oleh karena itu banyak dari mereka yang bekerja sebagai pekerja 
seks dan pekerja kesenian. Hal tersebut dikarenakan memang pendidikan mereka memang rendah (wawancara dengan Handayani, 19 Juni 2012 dan responden L, 20 Juni 2012). Selain bekerja pada dua bidang tersebut, waria muda biasanya tidak mempunyai keahlian khusus, sehingga banyak waria yang mengikuti waria seniornya yang sudah mempunyai salon atau setidaknya bekerja di salon.

Latar belakang waria yang seperti itu membuat banyak dari mereka yang tidak mandiri secara ekonomi.Oleh karena itu, belum adanya organisasi yang benar-benar menyentuh mereka secara ekonomi membuat mereka sering kesulitan dalam keuangan. Bahkan PERWAKOS sebagai naungan waria di Surabaya juga tidak memberikan bantuan dalam bentuk pemberian material uang, mereka lebih fokus pada penyebaran kondom untuk memperkecil penyebaran HIV dan AIDS (wawancara dengan responden A, 17 April 2011). Bahkan pemerintah juga seakan tidak menghiraukan keberadaan mereka.Bantuan BLT mempunyai syarat yang terlalu "ribet."

Hal yang paling utama dari penerima BLT adalah mempunyai KTP.Hal tersebut yang menjadi permasalahan banyak waria.Kebanyakan dari mereka tidak mempunyai KTP yang bisa dijadikan dasar hukum seseorang tinggal di daerah tertentu.

Dengan segala keterbatasan tersebut, waria memang jarang mendapatkan bantuan dana dari pihak manapun. Hal inilah yang ditangkap oleh organisasi keagamaan waria.Untuk menjaring jemaat, PHDK memberikan banyak akses yang secara ekonomi menguntungkan bagi waria. Tiap sekali datang ke persekutuan doa, waria akan mendapatkan uang transport dan makan malam. Selain itu, pada beberapa acara tertentu seperti Natal, Paskah, dan hari keagamaan Kristen lainnya mereka bahkan mendapat bingkisan sembako.Pada saat observasi, peneliti melihat bahwa tiap individu mendapatkan kopi satu "renteng," mi instan, biskuit yang bisa dijadikan bekal.

Hal tersebut belum termasuk bantuan dari Bukit Zion yang berupa bantuan kesehatan, dan bahkan bantuan ekonomi secara penuh bagi mereka yang sudah siap untuk berubah (wawancara dengan responden B, 22 Juni 2012). Hanya saja Bukit Zion memang terbatas pada waria yang mempunyai KTP, dan di dalam KTP tersebut berlaku nama aslinya. Bantuan dari Bukit Zion tidak terbatas dalam hal itu saja, tetapi juga pemberian makan dan unag transport pada kebaktian hari Minggu. Intinya waria yang ingin datang tidak harus mengeluarkan uang apapun, mereka hanya membawa tubuh saja saat datang baik ke persekutuan doa atau kebaktian. 
Pemberian bantuan dari gereja Bethany juga merupakan bentuk kapital ekonomi yang didapatkan oleh anggota PHDK. Waria yang dibaptis di gereja tersebut dan sudah berusia manula akan mendapatkan bantuan hidup bulanan sebesar Rp. 150.000 dan juga mendapatkan bantuan uang kos sebesar Rp. 300.000 dalam satu tahun (wawancara dengan Handayani, 26 Juni 2012). Meskipun secara nominal tidak banyak, tetapi uang tersebut setidaknya bisa diandalkan oleh waria manula yang kebanyakan sudah tidak memiliki pekerjaan tetap.Sampai saat ini sudah ada 10 waria yang mendapatkan bantuan dari gereja tersebut (ibid, 26 Juni 2012).

Hal serupa juga ditawarkan oleh pengajian Al-Ikhlas. Berhubung mereka berada pada kelas ekonomi yang lebih tinggi, maka ekonomi pun bekerja dengan cara yang lain. Waria anggota pengajian memilih untuk mengadakan iuran bulanan yang nantinya diberikan kepada anggota yang mengalami kesusahan.Kesusahan tersebut bisa dalam bentuk sakit atau saat mereka meninggal. Selain itu dalam hal penyediaan "suguhan" saat pengajian juga dibantu dari dana iuran bulanan tersebut. Meskipun jumlahnya sedikit, hal tersebut juga menjadi pemicu mengapa organisasi ini tetap berjalan dan berkembang sampai saat ini.

\section{Waria dan Rekognisi}

Semua kapital, mulai dari kapital ekonomi, dan budaya, pasti pada ujungnya akan bermuara pada kapital simbolik. Kapital simbolik merupakan hierarki tertinggi dalam kapital, yaitu kekuasaan yang memungkinkan untuk mendapatkan setara dengan apa yang diperoleh melalui kekuasaan fisik dan ekonomi, berkat akibat khusus suatu mobilisasi (Haryatmoko, 2003). Kapital ini bisa berupa gelar pendidikan yang dicantumkan di kartu nama, cara bagaimana membuat tamu menanti, cara mengafirmasi otoritasnya, dan lain-lain. Kapital simbolik ini juga bisa diwujudkan dalam bentuk rekognisi terhadap kaum-kaum/golongan-golongan yang termarjinalkan. Sebagai contoh adalah golongan waria yang memang di dalam masyarakat selalu didiskriminasikan dan dimarjinalkan.

Waria dan agama merupakan dua hal yang oksimoron, dimana keduanya saling bertentangan. Banyak agama tidak mengakui adanya waria, tetapi waria masih tetap eksis di masyarakat. Keberadaan organisasi keagamaan yang menanungi waria pun tak pelak menjadi sorotan karena bisa menjembatani antara dua hal yang sangat bertolak belakang. Kondisi yang demikian pada akhirnya menimbulkan banyak pertanyaan pada masyarakat sekitar anggapan bahwa waria hanya yang hidup 
di jalanan dan berprofesi sebagai pekerja seks menjadi pudar. Bagi sebagian orang, stigma seperti itu bisa dikurangi selama organisasi keagamaan ini berjalan dengan baik.

Pada kasus pengajian Al-Ikhlas dimana letak pengajiannya selalu berubah-ubah setiap kali pelaksanaannya menjadi poin sentral dalam upaya waria dalam mencari pengakuan.

"Dengan pindah-pindah, masyarakat bisa melihat bahwa waria juga ada sisi positifnya" (wawancara dengan responden $\mathrm{J}, 11$ Mei 2012)

Perpindahan lokasi tersebut seakan menandai dan menginformasikan pada masyarakat sekitar bahwa waria tidak hanya yang "mejeng" di jalan dengan rok pendek dan menjajakan tubuhnya pada lelaki hidung belang. Waria juga bisa ngaji dan melakukan kegiatan keagamaan secara rutin. Bahkan di suatu waktu, ada pengajian waria yang juga mengundang masyarakar sekitar (wawancara dengan informan A, 11 Mei 2012). Dengan bergabungnya masyarakat sekitar dalam kegiatan pengajian tersebut menandakan bahwa batas-batas antara waria dan masyarakat seakan luntur. Stigma buruk yang dulunya selalu menempel pada mereka lambat laun luruh dan digantikan dengan pendapat yang positif.

KTA (Kartu Tanda Anggota) yang dimiliki oleh tiap-tiap anggota juga menjadi salah satu kapital simbolik yang dapat mereka miliki. Mayoritas waria tidak mempunyai KTP, atau setidaknya KTP yang mereka miliki berasal dari daerah asal mereka, bukan KTP Surabaya. Dengan adanya KTA, maka itu bisa dijadikan simbol bahwa mereka terdaftar sebagai penduduk Surabaya meskipun secara tidak resmi. "Aku duwe KTA, iki lumayan lan lah gawe didudohno." "Saya mempunyai KTA, ini lumayan untuk ditunjukkan.” (wawancara dengan informan A, 11 Mei 2012). Meskipun tidak ada jaminan bahwa KTA tersebut bisa meloloskan mereka dari operasi yustisi, tetapi setidaknya hal tersebut menjadi semacam "pegangan” yang berguna bagi waria anggota.

Isi pengajian yang bermuatan ringan dan mudah dipahami juga menjadikan kunci bagi waria untuk mendapatkan sari pengetahuan agama dari pengajian tersebut. Salah satu anggota dari pengajian tersebut merasa bahwa dengan menjadi anggota dari pengajian, rasa percaya dirinya menjadi bertambah, karena mendapatkan pengetahuan agama dan melakukan sesuatu sesuai dengan perintah Allah (wawancara dengan informan B, 1 Mei 2012). Biasanya waria tersebut malu untuk melakukan 
sholat Jumat di masjid dekat rumahnya, tetapi sekarang dia tidak malu dan bisa membaur ke dalam masyarakat.

Kostum/busana yang dikenakan pada saat pengajian berlangsung juga membawa manfaat yang cukup signifikan terhadap waria anggota. Mereka menjadi paham bahwa hakikat mereka dalam beribadah adalah sebagai pria bukan sebagai wanita.

Manfaat pengajian juga diakui Linda. Pemilik Linda Salon di Jalan Kendangsari itu mengaku gaya hidupnya mulai berubah sejak dirinya rutin mengikuti pengajian Jumat Manis. Dia yang sebelumnya menjalankan salat di rumah dengan rukuh, seperti layaknya perempuan, kini mulai berani unjuk muka. Setiap Jumat, dia pergi ke masjid dengan pakaian muslim. "Bahkan, setiap selesai ibadah, saya dipanggil takmir dan diajak berdiskusi. Itu artinya, keberadaan saya diterima," ungkapnya (Satriyo, 2006).

Penerimaan takmir masjid terhadap keberadaan seorang waria merupakan hal yang luar biasa di Indonesia. Seringkali waria malu untuk masuk ke masjid dan melakukan ibadah, tetapi dengan adanya pengajian, waria semacam mendapatkan pengetahuan agama yang membuat mereka "berani" untuk berdiskusi dengan anggota masjid yang lain.

Dengan adanya pengajian ini setidaknya waria mendapatkan pengertian bahwa secara syariat mereka masih dikategorikan sebagai laki-laki. Maksudnya adalah ketika mereka menjalani ibadah, mereka harus kembali ke sejatinya mereka, sebagai laki-laki. Sebagai contoh pada saat sholat, mereka tidak diperkenankan memakai mukena seperti layaknya perempuan, melainkan mengenakan peci dan sarung seperti laki-laki. Hal semacam ini membuat mereka semakin percaya diri ketika menjalankan ibadah yang diperintah Allah, termasuk yang termasuk salah satu rukun Islam terakhir yaitu menunaikan ibadah haji.

Persoalan mengenai haji ini menjadi fenomena yang unik di kalangan waria. Mak Anik sebagai pemrakarsa pengajian ini sudah pernah menunaikan ibadah haji sekali, dan berencana untuk menunaikan lagi pada tahun 2012, tetapi tidak kesampaian karena telah meninggal. Boellstroff pernah mengatakan bahwa waria menunaikan ibadah haji atau mengirim orang tuanya untuk berangkat haji 
bertujuan untuk menghapus dosa. Kebaikan (good deeds) bisa menjadi kompensasi mereka menjadi waria (2011: 166).

Dia mengaku banyak mendapat manfaat dari pengajian Al- Ikhlas itu. "Yang jelas, saya bisa beribadah. Saya mengenal Tuhan," ungkap waria 41 tahun itu. Dia menargetkan, jika rezekinya lancar, dua tahun mendatang bakal menyusul Marini ke Tanah Suci. "Doakan saya bisa naik haji," terang waria berambut panjang itu. (Satriyo, 2006)

Seiring dengan keinginan mereka untuk menghapus dosa, waria yang telah mendapatkan predikat sebagai haji akan memperoleh privilege spesial setidaknya jika bukan untuk keluarganya tetapi bagi masyarakat. Satu hal yang berubah ketika menjadi haji adalah mengenai addressing/panggilan orang lain terhadap mereka. Orang memanggil mereka tidak dengan panggilan mbak/ibu lagi tetapi dengan panggilan haji. Hal tersebut merupakan salah satu penanda bahwa mereka eksis dan bisa menunaikan ibadah haji.

Dengan munculnya rekognisi terhadap kalangan waria, maka secara tidak langsung akan membuka penerimaan masyarakat terhadap waria. Salah satu waria mengatakan bahwa ia sekarang tidak hanya mengikuti kegiatan keagamaan Al-Ikhlas, tetapi juga mengikuti pengajian-pengajian yang lain. Haji merupakan salah satu kapital bagi waria untuk mendapatkan pengakuan di mata masyarakat dan juga menjadi penanda keberhasilan waria di bidang keagamaan.

\section{Simpulan}

Organisasi keagamaan waria merupakan solusi yang lengkap di dalam pengurangan diskriminasi dan stigma masyarakat terhadap mereka.Tempat tersebut memang ditujukan bagi para waria yang selama ini mendapatkan kesulitan untuk mencari tempat beribadah yang nyaman.Tidak ada lagi istilah waria yang malu atau sungkan untuk pergi ke tempat ibadah, karena keberadaan organisasi keagamaan waria mewadahi semua keinginan waria di dalam beribadah.

Dalam sejarahnya, organisasi keagamaan waria ini tumbuh untuk menyuarakan keinginan waria dalam beribadah.Tidak hanya itu, berdirinya organisasi juga dipengaruhi oleh habitus dari pesertanya.Habitus tersebut bisa berupa pengalaman sejarah ketua dan anggota yang dahulu dibesarkan di lingkungan yang relijius. Hal tersebut juga membawa efek dalam cara berpakaian waria ketika melaksanakan ibadah pengajian, yaitu dengan memakai pakaian laki-laki dan tanpa make-up. 
Pada ranah inilah, habitus yang berupa etos bekerja, yaitu dengan mengarahkan anggota sesuai dengan pemikiran Ketua, baik dalam pelaksanaan ibadah ataupun pencapaian tujuan bersama. Sementara habitus hexisbekerja dalam cara berpakaian waria dan bagaimana pembawaan waria di dalam pelaksanaan ibadah.

Tembok/force field di dalam arena yang berfungsi menjadi filter untuk menahan sesuatu dari dalam untuk keluar dan sebaliknya juga muncul di dalam pelaksanaan ibadah pada organisasi keagamaan waria. Tembok yang berupa konsepsi dari masyarakat dan norma agama merupakan tembok yang bisa ditembus dengan negoisasi antara waria dan agama. Arena ini terlihat pada saat waria mengadakan ibadah di dalam dan di luar organisasinya. Ketika berada di "lingkungan dalam", waria terkesan lebih santai dibanding jika ibadah dilakukan di "lingkungan luar" yang menuntut mereka untuk menjadi lebih normatif. Ceramah yang diberikan oleh pemuka agama baik Islam ataupun Kristen juga memberikan ruang bagi waria untuk menjadi waria, meskipun tujuan akhirnya adalah mengembalikan mereka sesuai dengan jenis kelamin mereka.

Habitus, Arena, dan Kapital menjadi tiga hal yang tidak bisa dipisahkan ketika berbicara mengenai Teori Praktik.Begitupun juga dengan keberadaan organisasi keagamaan waria ini, yang tidak bisa lepas dari kapital.Dalam pelaksanaan organisasi keagamaan, terdapat tiga kapital yang diperebutkan, kapital sosial, kapital ekonomi, dan kapital simbolik.Kapital sosial berbentuk organisasi keagamaan sebagai tempat waria untuk bersosialisasi dengan yang lain serta dalam pengurusan kematian waria yang selama ini selalu menjadi momok bagi waria.Kapital ekonomi muncul dalam bentuk pemberian bantuan materi kepada anggota organisasi.Meskipun tidak banyak tetapi kapital ekonomi menjadi penting kaitannya dengan waria yang berada dalam kelas ekonomi menengah kebawah. Kapital simbolik muncul berupa rekognisi akan keberadaan waria dalam pandangan yang lebih baik. Meskipun diskriminasi tidak hilang sepenuhnya, tetapi masyarakat telah melihat sisi positif waria, dan itu penting bagi perjalanan waria dalam mengupayakan rekognisi.

Secara keseluruhan, munculnya organisasi keagamaan waria membuktikan bahwa waria sudah selangkah lebih maju dalam mendapatkan rekognisi dari masyarakat. Rekognisi ini penting adanya karena sebagai kelompok minoritas dan marjinal, komunitas waria perlu untuk mendapatkan rekognisi tidak dalam hal yang negatif, tetapi dari hal yang positif. Kegiatan ini merupakan kegiatan 
positif yang bisa dilaksanakan oleh waria dan oleh karenanya organisasi semacam ini harus didirikan di kota-kota dimana komunitas waria ada dan tinggal.

Penelitian lebih lanjut perlu dilakukan pada komunitas waria pada agama-agama lain di Indonesia. Apakah organisasi keagamaan waria Hindu, Budha, dan Katolik (apabila ada) juga berfungsi sama dengan organisasi keagamaan waria Islam dan Kristen Protestan. Lebih lanjut, kelas sosial waria yang tidak tercantum di dalam penelitian ini, seperti waria Islam dengan status ekonomi menengah kebawah dan waria Kristen Protestan dengan status ekonomi menengah keatas juga perlu diteliti lebih lanjut. Selain itu, penelitian lebih lanjut juga perlu dilakukan terhadap organisasi keagamaan yang berada di daerah selain Surabaya yang mempunyai karakteristik yang kurang lebih sama. Untuk memperkaya kajian tentang arena, perlu dilakukan studi khusus mengenai sejarah waria di Surabaya secara spesifik.

\section{Daftar Acuan}

Alwasilah, C., 2011, Pokoknya Kualitatif. Jakarta: Pustaka Jaya.

Anggraeni, F., 2003, Beralas Tikar, Lagu Tulisan Tangan, Dan Memuji Tuhan. 133 ed. Surabaya: Tabloid Gloria.

Anggraeni, F., 2003, PD Waria Sarana Pertobatan atau Pengakuan?. 141 ed. Surabaya: Tabloid Gloria.

Ariyanto \& Triawan, R., 2008, Jadi, Kau Tak Merasa Bersalah: Studi Kasus Diskriminasi dan Kekerasan Terhadap LGBTI. Jakarta: Citra Grafika.

Boellstroff, T., 2008, Playing Back The Nation: Waria, Indonesia Transvestives. Irvine: University of California.

dar, 2002, Gereja Harus Berdamai dengan Waria. Surabaya: NARWASTU.

Dr. Deddy Mulyana, M., 2006, Metodologi Penelitian Kualitatif. Bandung: PT. Remaja Rosdakarya. Field, J., 2010, Modal Sosial. Bantul: Kreasi Wacan Offset.

Golub, S. A. et al., 2010, The Role of Religiosity, Social Support, and Stress-Related Growth in Protecting Against HIV Risk among Transgender Women. Journal of Health Psychology.

Handayani, 2012, PHDK [Wawancara] (27 April 2012).

Handayani, 2012, PHDK [Wawancara] (19 Juni 2012).

Handayani, 2012, PHDK [Wawancara] (22 Juni 2012). 
Haryatmoko, 2003, Menyingkap Kepalsuan Budaya Penguasa. dalam: Majalah Basis Edisi Khusus Bourdieu. Yogyakarta: Kanisius.

Ida, R., 2011, Metode Penelitian Kajian Media dan Budaya. Surabaya: AUP.

Jenkins, R., 2004, Membaca Pikiran Pierre Bourdieu. Yogyakarta: Kreasi Wacana.

Kesehatan, D., 2009, Laporan Estimasi Populasi Rawan HIV di Indonesia, Jakarta: Departemen Kesehatan.

Kortschak, I., 2010, Invisible People: People and Empowerment in Indonesia, Jakarta: Go Down and Lontar Foundation.

Lombardi, E. L., 2008, "Integration Within a Transgender Social Network and Its Effect upon Members' Socialand Political Activity," dalam Jourrnal of Homosexuality, 37(1), pp. 109-126.

Maton, K., 2008, "Habitus," dalam M. Grenfell (Ed.) Pierre Bourdieu Key Concepts. Durham: MPG Books.

Megawati, R., 2011, Ketika Waria Bertasbih: Sebuah Studi Kasus tentang Waria dan Relijiusitas. Surabaya: s.n.

Moh. Nazir, P., 2011, Metode Penelitian. Bogor: Penerbit Ghalia Indonesia.

Moore, R., 2008, "Capital" dalam M. Grenfell (Ed.) Pierre Bourdieu Key Concepts. Durham: MPG Books.

Muhammad, H., Mulia, S. M. \& Wahid, M., 2011, Fiqh Seksualitas. Jakarta: PKBI.

Mutahir, A., 2011, Intelektual Kolektif Pierre Bourdieu. Bantul: Kreasi Wacana.

Nuraini, F., 2011, Ketika Waria Surabaya Bertasbih. Surabaya: Koran SURYA.

Pinto, R. M., Melendez, R. M. \& Spector, A. Y., 2008, "Male-to-Female Transgender Individuals Building Social Support and Capital From Within a Gender-Focused Network," Journal of Gay and Lesbian Social Services, 20(3), pp. 203-220.

Robbins, D., 200,. "Theory of Practice," dalam M. Grenfell (Ed.) Pierre Bourdieau Key Concepts. Durham: MPG Books.

Safitri, D. M., 2011, Piety Revisited: The Case of Pesantren Al-Fattah Senin-Kamis Yogyakarta. Yogyakarta: s.n.

Satriyo, A., 2006, Kelompok Pengajian Jumat Manis yang Anggotanya Para Waria Surabaya. Surabaya: Jawa Pos.

Swartz, D., 1997, Culture and Power: The Sociology of Pierre Bourdieu. Chicago: University of Chicago Press.

Thomson, P., 2008, Field. In: M. Grenfell, ed. Pierre Bourdieu Key Concepts. Durham: MPG Books. 
Wariazone. 2011. [Film] Directed by Terje. Indonesia: s.n.

\section{Wawancara}

Handayani, 58 tahun, waria Protestan, wawancara pada 27 April 2012, 19 Juni 2012, dan 22 Juni 2012

Informan A, 38 tahun, waria Islam, wawancara pada 11 Mei 2012

Informan B, 54 tahun, laki-laki Islam, wawancara pada 1 Mei 2012

Informan C, 64 tahun, laki-laki Protestan, wawancara pada 22 Juni 2012

Informan D, 70 tahun, waria Protestan, wawancara pada 27 April 2012

Responden A, 40 tahun, waria Islam wawancara pada 17 April 2011

Responden B, 43 tahun, laki-laki Protestan, wawancara pada 21 Juni 2012

Responden C, 40 tahun, laki-laki Protestan, wawancara pada 14 Maret 2012

Responden D, 67 tahun, waria Islam, wawancara pada 27 April 2012

Responden E, 25 tahun, waria Islam, wawancara pada 27 April 2012

Responden F, 56 tahun, waria Islam, wawancara pada 11 Mei 2012

Responden G, 35 tahun, waria Islam, wawancara pada 27 April 2012

Responden H, 66 tahun, waria Protestan, wawancara pada 20 Juni 2012 